\title{
Central bank transparency: cross-country comprehension (example of inflation reports)
}

\author{
Abdul Rahman Barhaq \\ Deputy Chief Financial Officer, Da Afghanistan Bank (Central Bank of Afghanistan), Afghanistan
}

\begin{abstract}
Alona Zakutniaia
Ph.D., Senior Economist, National Bank of Ukraine, Monetary Policy and Economic Analysis Department, Ukraine
\end{abstract}

\begin{abstract}
Implementation of inflation targeting strategy by central bank is connected with public announcement of inflation targets and central bank's obligation to achieve these goals. The main element of the central bank's communication policy in terms of implementing the inflation targeting strategy is the inflation report. The study offers three methods of assessing the quality of inflation reports: 1) expert method (an evaluation of the inflation reports produced by 15 inflation-targeting central banks considering the following criteria: how convincing the report is judged to be, how users trust the central bank, how decisions on monetary policy are fully argued; how complete the report is and the overall assessment of the report); 2) readability test (Flash index calculation, "target audience" definition); 3) content analysis of inflation reports (by using ABBYY FineReader 9.0, ATLAS.ti 7, QDA Miner Lite software). We find that variables that characterize the quality of the inflation report are closely negatively related to the degree of change in the market participants expectations of interest rate. Statistical relationship between the quality of inflation reports and predictability of monetary policy was proved by using STATISTICA 10 package.
\end{abstract}

Keywords: transparency, inflation report, monetary policy, inflation targeting.

JEL Classification: E52, E58, H50, H60, H70.

DOI: $10.21272 /$ bel.1(2).47-54.2017.

(C) The Authors, 2017. This article is published with open access at ARMG Publishing.

\section{Introduction}

Monetary policymaking has undergone a dramatic transformation during the last 25 years. Central banks used to be known for their secrecy, leaving people to guess their intentions. But nowadays most monetary regulators publicize their objectives with quantitative targets and publish numerical macroeconomic forecasts. They have also become much more open about their policy decisions and several ones even give explicit guidance about upcoming policy moves. Transparency has become a key feature of monetary policymaking and central banks consider it very important. This is partly because a lot of central banks have become independent, which has been accompanied by formal accountability requirements. Moreover, in the past fifteen years several countries have adopted inflation targeting regime. The key advantage of this regime is that monetary policy is guided by a simple, logical criterion: the gap between forecasted and target inflation. Implementation of inflation targeting strategy by central bank relates to public announcement of inflation targets and central bank's obligation to achieve these goals. Inflation targeting central banks use many communication tools, such as press releases, press conferences, a variety of written documents and, increasingly, websites. But inflation reports have become the main element of communication policy of inflation targeting central banks. That is why it is necessary to assess the quality of the inflation reports of central banks that use inflation targeting regime. The results from that survey are useful for conducting an empirical study of the relationship between the characteristics of inflation reports and the predictability of monetary policy (market participant's expectations of interest rate). Scholars from various disciplines such as social sciences, communications, psychology, political science, history, and language studies use content analysis, but there are a few studies using this method in economic studies (specially as a method of evaluation the quality of the inflation report). Thus, the aim of this paper is to investigate a comprehensive analyse of inflation reports (in- 
cluding content analysis) and to determine the effect of inflation reports quality on market participant's expectations.

\section{Literature review}

Term "transparency" is used in the scientific literature to indicate a state of complete awareness and information disclosure about particular object or process (Chub, 2008). Nowadays this concept is one of the most common and key in various fields of knowledge, but there is no generally accepted scientific definition. This is due to multidimensional of transparency, variety of its application in various fields of science and practice. The analysis of the relevant economic literature confirmed the absence of common approach to the interpretation of the term "transparency". We consider it is appropriate to analyse following approaches in more detail. The first one is that term "transparency" is equal to the term "information" (Stiglit, 2000). In our opinion, this approach is not grounded enough. In this case answer for the question "What information means and for whom it is designed?" is not given. It is obvious that transparency is a characteristic of information. The second approach determines transparency as a system of relations concerning disclosure of information and its use (Hubiev, 2009). Supporters of the third approach consider that transparency is determined by the availability, completeness, accuracy, timeliness and clarity of information (Litovskih, 2006; Melnik, 2010; ECB, 2011).

Scientists identify four main characteristics of transparency, which include accessibility of information (provision of information in open access or on the first request), completeness of information coverage (provision of sufficient volume of information to explain past and future actions of a central bank), timeliness (information should be provided with a minimum delay), integrity of information (tools and channels of information policy should be consistent and coordinated with each other) (Dincer \& Eichengreen, 2014; Mishkin, 2004). In our opinion, listed characteristics reflect only amount and structure of provided information. It is not always the evidence of its usefulness for consumers. We propose to add important characteristic - quality of provided information. No matter how often central bank publishes information, if it is confusing or useless to society; monetary policy will not be considered as transparent. Also, presence of "information intermediaries" was ignored in the scientific literature we have analysed. The role of information intermediaries (variety of media: TV, radio, periodicals, etc.) is to transfer information from central bank to consumers. If information is distorted by intermediaries, public perception of central bank actions will be distorted too.

Therefore, based on the above analysis, we have formulated our approach to the definition of "transparency" a disclosure of the central bank (directly or via intermediaries) to businesses and individuals information that related to legal, institutional and economic basis of development and implementation of monetary policy in an open, clear and timely manner.

The level of transparency is assessed by using a special index. The first index of transparency was published in 2002 by P. Siklos. It consisted of 11 variables related to the method of providing information, understanding of monetary regulation, and publicity of monetary policy procedures and independence of the central bank (Siklos, 2002).

S. Eijffinger and P. Geraats identified five main components of transparency (political, economic, procedural, policy, operational transparency). Evaluation was carried out by using binary parameters (0 and 1$)$ (Eijffinger \& Geraats, 2006). The similar method of assessing the level of transparency was chosen by N. Dincer,

B. Eichengreen, but their research was based on 150 central banks (not 20 as in the previous case) (Dincer \& Eichengreen, 2013).

The peculiarity of index proposed by D. Stasavage is its components, based on four questions about form of publications, disclosure of long-term forecast, publication of information about risks and discussions concerning past mistakes (Stasavage, 2003).

A growing number of developing countries are practicing inflation targeting as a monetary policy framework. For the first time inflation targeting regime was introduced by central bank of New Zealand in December, 1989 (Quinonez, 2015). But today the number of countries that have implemented the inflation target regime is 43 , and 15 of them - with high income, 15 - with incomes above the average, 11 - below average, 2 - low income (see Figure 1). Finland, Spain and Slovakia are countries where central banks have formally ceased to use infla- 
tion targeting since these countries joined the EU and delegated regulation of monetary policy to the European Central Bank.

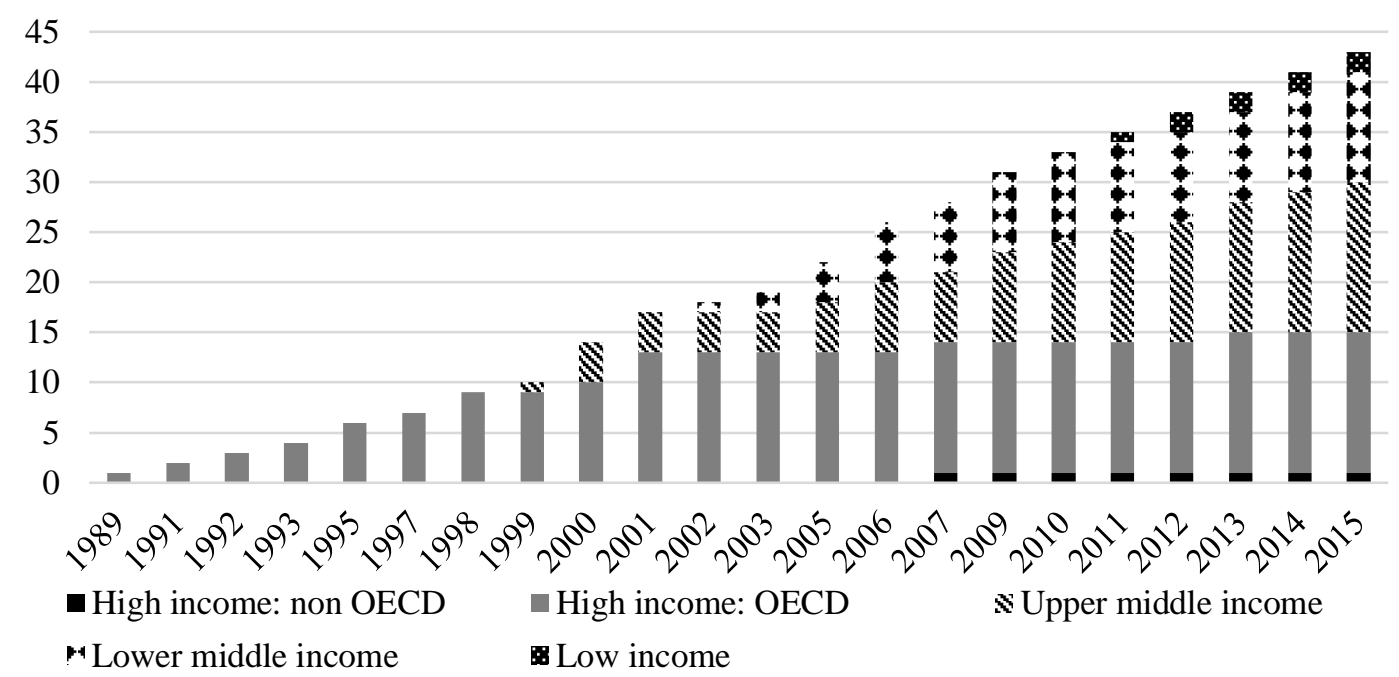

Figure 1. Chronology of inflation targeting implementation in the world

Source: Quinonez, 2015.

It should be note that in the inflation targeting monetary framework an inflation target is set and publicly announced, then policy-makers will do whatever best in order to achieve said goal. Countries that have adopted this monetary framework have experienced lower and more stable inflation rate. These two benefits help consumers and producers base their economic decisions and plan their consumption and investment plans, ultimately boosting GDP and economic growth (Quinonez, 2015). Inflation targeting central banks use many communication tools, such as press releases, press conferences, a variety of written documents and, increasingly, websites. But inflation reports have generally become the central element of communication policy of inflation targeting central banks. It is necessary for inflation reports to present the inputs into decisions (data, forecasts, analyses), the decision process itself, and the possible risks associated with the chosen policy. Also inflation repots should be done in a complete, yet concise manner (A. Fracasso, 2003). A. Fracasso (2003) also offers an evaluation methodology of the inflation reports. To do so, it relies on a questionnaire completed by independent evaluators, covering an exhaustive list of attributes.

Since central banks release carefully constructed inflation reports to the public, in our opinion, applying text-mining techniques to those reports can help quantify this information to provide a rich analytical resource reflecting real time economic and financial analysis. The analysis of relevant literature demonstrate that text mining method is widely applied in other fields such as political science, business management, communication and marketing, but it has been historically less used in economic science. However, central banks can use these techniques to reach and analyse a range of data sources.

For example, Schonhardt-Bailey (2013) used text analysis to examine Fed FOMC transcripts. Romer \& Romer (2004) examined such documents to extract a narrative-based examination of the impact of monetary policy shocks. Fligstein, Brundage and Schultz (2014) applied LDA to Fed minutes from the years 2000 to 2007. They examine the documents within the framework of the sociology field of "sensemaking", finding consistencies with the theory. In addition, Hansen et al. (2014) applied LDA to a dataset from the Greenspan era (1987-2006) and developed a range of measures of communication patterns at the meeting-section-speaker level. Cannon (2015) analysed the FOMC transcripts from 1977 to 2009 by measuring the tone of FOMC deliberations, exploring the differences across speakers and examining how the tone of the discussions relates to a measure of economic activity.

\section{Methodology}

Taking to account the above-described literature, we can clarify objectives that were set out in the paper. The first one is to assess the quality of central banks inflation reports based on the A. Fracasso (2003) 
methodology. The second one is to determine the relationship between the quality of inflation reports and market participant's expectations of interest rate. And the third objective is to analyse inflation reports of the National Bank of Ukraine by content analysis method.

So, first of all, we identified 14 countries (Australia, the United Kingdom, Iceland, Israel, Canada, Thailand, New Zealand, Norway, South Africa, Poland, Hungary, the Czech Republic, Sweden, Switzerland) to assess the quality of the inflation report of central banks that have implemented inflation targeting regime in view of ensuring monetary policy transparency. We used A. Fracasso (2003) methodology that is based in the formation of a group of ten experts ( 5 economists and 5 people without special education). Experts should fill in the questionnaire with 25 questions relating to the quality of the inflation report published by the central banks in 2016. The main drawbacks of this method, in our opinion, are the following: a relatively small number of experts and assessing only one year report (in some countries perhaps this year was transition or crisis). But due to limited resources, we cannot attract a large number of experts to analyse the inflation reports for several years.

On the second stage of our study based on methodology for assessing the quality of inflation reports, we estimated the relationship between the quality of inflation reports and market participants expectations of interest rate. As a basic model, we offered to use regression equation proposed by A. Fracasso (2003):

$\Delta i_{t}^{h}=\alpha_{0}+\sum_{j=1}^{n} \alpha_{j} C h_{i}^{j}+\sum_{k=1}^{m} \beta_{k} C_{i}^{k}+u_{i}$,

where $\Delta i_{t}^{h}$-change in market participants expectations of interest rate;

$C h$ - characteristics of inflation reports, which affect the perception of market participant's monetary policy decisions;

$C$ - macroeconomic indicators, which affect the perception of market participants monetary policy decisions (control variables).

Then we calculated the degree of change in market participants expectations of interest rate regarding the meetings of the Monetary Policy Committee:

$\Delta i_{t}^{h}=i_{t+1}^{h}-i_{t-1}^{h}$,

where $\Delta i_{t}^{h}$-change in market participants expectations of interest rate;

$i_{t \mp 1}^{h}-$ market interest rate on debt obligations of horizon $h(1,3$ and 12 months) at date $t$ (the day an Monetary Policy Committee meets to take a decision on whether to increase, decrease or leave unchanged its interest rate).

Also we identified variables we use to characterize the quality of the information in the inflation reports: convincing $(C O N V)$ - how convincing the report is judged to be, how users trust the central bank, how decisions on monetary policy are fully argued; complete $(C O M P)$ - how complete the report is, does the expert find all the answers to the questions that come to mind? overall assessment of the report $(C O M B)-$ unweighted average of these four ratings.

The predictability of monetary policy (interest rate) is likely to be influenced not only by the clarity of the monetary policy analysis and communication of the central bank, but also by the macroeconomic situation in which the policy decisions are taken. That's why we introduced the following variables in regression: the average level of inflation during the analysed period (IL); average of the GDP growth (GDP).

The third step of our study was to conduct "text mining" analysis of inflation reports of the National Bank of Ukraine using ABBYY FineReader 9.0, ATLAS.ti 7, QDA Miner Lite software and online services textminingonline.com and sd1.su/online-service/text-index. The results helped to determine the main objectives of the National Bank of Ukraine and estimate quality of content of the inflation report. We analysed six reports for the years 2015-2016. The methodology of analysis is shown schematically in Figure 2 (see in Appendix).

\section{Results}

The first step of our study was to assess the quality of inflation reports of central banks. The results of four main evaluation criteria are shown in Table 1 (see in Appendix). The first assessment criterion is "con- 
vincing" of the report. Its essence lies in assessing the credibility of users to central bank actions by determining the level of central bank decisions argumentation. So, according to the results reports are generally convincing with few exceptions. The next evaluation criterion is the completeness of the report (does the expert fined all the answers to the questions that come to mind?). The results show that some central banks (Switzerland, Australia and Poland) deliberately did not include all the information to the inflation report and announce it through other communication tools. As a result, it is difficult to ordinary people without proper education to find necessary information. Furthermore, some important information is published once a year in the annual report of the banks. In this context, the following criterion is important. It is the "writing style". It shows whether the message of the report is conveyed clearly. Most central banks have been highly valued with few exceptions (which may be related to the translation into English). The last criterion is "information provided" (does information about all macroeconomic indicators fully disclosed?). It should be noted that the information about the inflation and current prices is fully disclosed. The worse situation is with information about economic growth. Thus, even central banks that use the Taylor rule do not provide complete information about the pace of economic growth. The amount of information provided on growth tends to be significantly less adequate than on inflation. This may reflect a genuine emphasis of the central bank on inflation. Alternatively, it may be a desire to underplay the role of growth in shaping monetary policy. We also use the unweighted average of these four ratings showed in Table 1 ("combined"). As a result, the Bank of England received the highest rating. It publishes the most informative and detailed inflation report. Inflation report of the Reserve Bank of New Zealand (country that first introduced inflation targeting regime and began publishing inflation reports) is next on quality. Interpretation of the second stage survey results is shown in Table 2.

Table 2. Regression results (determinants of market participants expectations of interest rate)

\begin{tabular}{|c|l|c|c|c|}
\hline \multirow{2}{*}{ Equation } & \multicolumn{1}{|c|}{ The form of equation } & $R^{2}$ & $\begin{array}{c}\text { Fisher criterion } \\
F_{f}>F_{t}\end{array}$ & $\begin{array}{c}\text { Significance of regression } \\
\text { coefficient } \\
\text { (Student's } t \text {-test) }\end{array}$ \\
\hline 1 & $\Delta i_{t}^{h}=-1.19+1.87 I L+1.2 G D P-0.28 C O N V$ & 0.79 & $6.89>3.71$ & all significant \\
\hline 2 & $\Delta i_{t}^{h}=-0.91+1.81 I L+1.16 G D P-0.31 C O M P$ & 0.81 & $7.33>3.71$ & all significant \\
\hline 3 & $\Delta i_{t}^{h}=-1.15+1.39 I L+0.75 G D P-0.28 S T Y L E$ & 0.83 & $7>3.71$ & all significant \\
\hline 4 & $\Delta i_{t}^{h}=-0.83+1.91 L+1.35 G D P-0.36 I N F$ & 0.79 & $7.65>3.71$ & all significant \\
\hline 5 & $\Delta i_{t}^{h}=-0.96+1.83 I L+1.23 G D P-0.35 C O M B$ & 0.88 & $7.86>3.71$ & all significant \\
\hline
\end{tabular}

Relationship between the quality of the inflation reports and market participant's expectations of interest rate was proved. Independent variables that characterize the quality of the inflation report (CONV, COMP, STYLE, INF , COMB) are closely negatively related to the degree of change in the market participants expectations of interest rate, the control variables $(I L, G D P)$ - positively related and therefore decisions on monetary policy more difficult to predict in terms of macroeconomic instability. Statistical significance of the models was confirmed by the coefficient of determination, which takes values from 0.79 to 0.92 and by the Student's t-test. On the third step of our study we conducted "text mining" analysis of inflation reports of the National Bank of Ukraine (NBU) (Figure 3, see in Appendix). Words were sorted by frequency as a result of text encoding with the use of software package QDA Miner Lite (tool "Coding Retrieval"). The most commonly used words during the analysed period were "price" and "GDP". Frequency of the words "targeting", "forecast" (information related to the inflation and other key macroeconomic indicators forecast) and "risk" (risks of monetary policy implementation) used in NBU's inflation reports has positive dynamics. These terms are crucial from the perspective of implementing the framework of inflation targeting and, therefore, from the fourth quarter of 2015 the NBU started to use unconventional tools of monetary regulation, including tools of communication policy, and to influence the expectations of economic agents by publishing forecasts and risks disclosing. Based on the results of the Flesh index calculation (Figure 4), that was designed to indicate how difficult a passage is to understand and enables to determine the level of education necessary for the inflation report's text perception. So we found that the NBU's reports are easy to understand by an audience of 11th grade and older. 


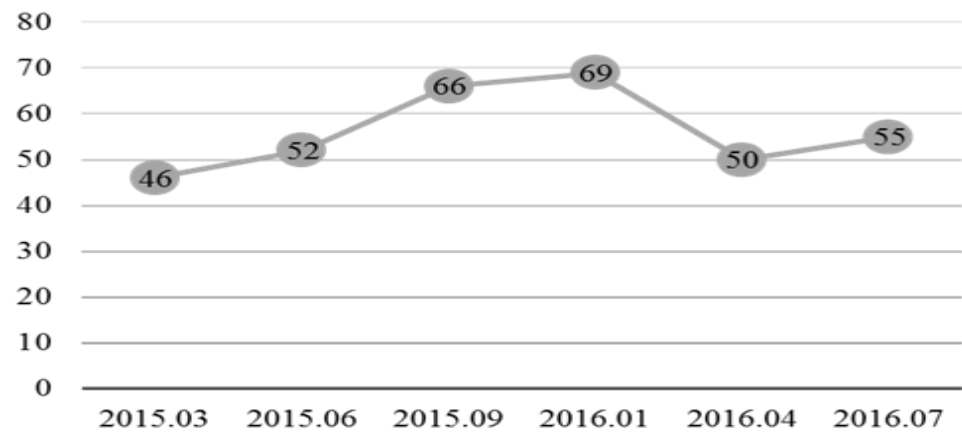

\section{Conclusions}

Figure 4. Results of the Flesh index calculation for the NBU's reports

This work studies inflation targeting inflation reports of central banks. The literature review clearly showed the availability of plethora of theoretical studies showing that in terms of globalization process intensification and significant volatility in world financial markets, the communication policy of central banks should be systematic and responsible. Objectivity, completeness and timeliness of the information provided by central banks determine the trajectory of economic decisions of individuals and entities, which form the dynamics of macroeconomic indicators and determine the effectiveness of monetary policy. Moreover, in the past fifteen years several countries have adopted inflation targeting regime. Implementation of inflation targeting strategy by central bank is connected with public announcement of inflation targets and central bank's obligation to achieve these goals. Generally, inflation reports have become the central element of communication policy. That is why it is necessary to assess the quality of the inflation report.

Therefore, we have set ourselves the task of comparative assessing the quality of inflation reports of central banks (including the NBU). First of all, we identified 14 countries to assess the quality of the inflation report of central banks that have implemented inflation targeting regime in view of ensuring monetary policy transparency. We used the methodology of A. Fracasso (2003). As a result, the Bank of England received the highest rating. It publishes the most informative and detailed inflation report. Inflation report of the Reserve Bank of New Zealand (country that first introduced inflation targeting regime and began publishing inflation reports) is next on quality. On the second stage of our study we proved the relationship between the quality of the inflation reports and market participant's expectations of interest rate. Finally, we conducted "text mining" analysis of inflation reports of the NBU. The results helped to determine the main objectives of the NBU and estimate the quality of content of the inflation report. We made a conclusion that from the fourth quarter of 2015 the NBU started to use unconventional tools of monetary regulation, including tools of communication policy, and influence the expectations of economic agents by publishing forecasts and risks disclosing.

\section{References}

1. Cannon, S. (2015). Sentiment of the FOMC: Unscripted. Federal Reserve Bank of Kansas City Economic Review (Fourth Quarter).

2. Chub, O.O. (2008). Pidvyshchennia transparentnosti ukrainskykh bankiv v umovakh hlobalizatsii" [Increasing the transparency of Ukrainian banks in the context of globalization]. Finansy, oblik $i$ audit, 166174.

3. Dincer, N.N. \& Eichengreen, B. (2014). Central Bank Transparency and Independence: Updates and New Measures. International Journal of Central Banking, 10(1), 189-259.

4. Eijffinger, S.C., \& Geraats, P.M. (2006). How transparent are central banks? European Journal of Political Economy, 22(1), 1-21.

5. Fligstein, N., Brundage, J.S., \& Schultz, M. (2014). Why the Federal Reserve Failed to See the Financial Crisis of 2008: The Role of "Macroeconomics" as a Sense Making and Cultural Frame. IRLE Working Paper, 111-114. Retrieved from http://irle.berkeley.edu/workingpapers/111-14.pdf. Accessed 21 June 2017.

6. Fracasso, A., Genberg H., Wyplosz, C. (2003). How do central banks write? An Evaluation of Inflation Targeting Central Banks. International Center for Monetary and Banking Studies. Retrieved from http://www.norges-bank.no/Upload/import/konferanser/2003-05-05/data/fracasso.pdf. $\quad$ Accessed 30 March 2017. 
7. Hansen, S., McMahon, M. \& Prat, A. (2014). Transparency and Deliberation within the FOMC: a Computational Linguistics Approach. CEP Discussion Paper, 1276.

8. Khubiiev, R.K. (2009). Transparentnost kak faktor konkurentosposobnosty" [Transparency as factor of competitiveness]. In Rossiiskoie priedprinimatielstvo, pp. 44-48. Retrieved from http://www.creativeconomy.ru/articles/5305. Accessed 30 March 2017.

9. Litovskikh, A.M. (2006). Transparency and its impact on the banking sector. Izvestiya TRTU.

10. Melnyk, K.K. (2010). Transparency as a necessary condition to ensure the effectiveness of central bank communication. Sumy. Problemy i perspektyvy rozvytku bankivskoi systemy Ukrainy, pp. 208-216.

11. Quinonez, S. Juan (2015). Inflation Targeting: A Panel Approach. Utah State University. Retrieved from http://digitalcommons.usu.edu/cgi/viewcontent.cgi?article=1693\&context=gradreports. Accessed 30 March 2017.

12. Romer, C.D. \& Romer, D.H. (2004). A New Measure of Monetary Shocks: Derivation and Implications. The American Economic Review, 94(4),1055-1084.

13. Schonhardt-Bailey, C. (2013). Deliberating American Monetary Policy: A Textual Analysis. Cambridge, MA: The MIT Press.

14. Siklos, P.L. (2002). Assessing the Impact of Changes in Transparency and Accountability at the Bank of Canada. Canadian Public Policy. Analyse de Politiques, 279-299.

15. Stasavage, D. (2003). Transparency, Democratic Accountability and the Economic Consequences of Monetary Institutions. American Journal of Political Science, 47(3), 389-402.

\section{Appendix}

Table 1. Assessing the quality of inflation reports of central banks

\begin{tabular}{|c|c|c|c|c|c|c|c|c|c|c|}
\hline \multirow[t]{2}{*}{ Country } & \multicolumn{2}{|c|}{ Convincing } & \multicolumn{2}{|c|}{ Completeness } & \multicolumn{2}{|c|}{ Writing style } & \multicolumn{2}{|c|}{$\begin{array}{l}\text { Information } \\
\text { provided }\end{array}$} & \multicolumn{2}{|c|}{$\begin{array}{l}\text { Unweighted average of indicator: } \\
\text { "convincing", "completeness", } \\
\text { "writing style", "information } \\
\text { provided" }\end{array}$} \\
\hline & value & $\sigma$ & value & $\sigma$ & value & $\sigma$ & value & $\sigma$ & value & $\sigma$ \\
\hline Australia & 4.62 & 1.82 & 3.26 & 1.33 & 7.83 & 1.70 & 4.28 & 1.33 & 5.00 & 1.54 \\
\hline United Kingdom & 9.66 & 0.43 & 9.08 & 0.20 & 10.30 & 0.00 & 9.38 & 0.41 & 9.61 & 0.26 \\
\hline Israel & 6.93 & 2.46 & 5.10 & 1.43 & 7.62 & 0.90 & 7.75 & 1.94 & 6.85 & 1.68 \\
\hline Canada & 5.67 & 1.35 & 4.49 & 1.12 & 9.27 & 0.70 & 7.47 & 0.91 & 6.73 & 1.02 \\
\hline New Zealand & 8.82 & 0.52 & 7.90 & 0.51 & 9.29 & 0.80 & 8.48 & 0.51 & 8.63 & 0.58 \\
\hline Norway & 7.14 & 1.14 & 5.82 & 1.53 & 7.68 & 0.90 & 7.27 & 0.40 & 6.98 & 0.99 \\
\hline South Africa & 6.09 & 0.83 & 4.78 & 1.33 & 7.07 & 0.70 & 5.51 & 1.38 & 5.86 & 1.06 \\
\hline Poland & 5.46 & 2.39 & 4.62 & 1.12 & 7.42 & 1.00 & 6.15 & 1.38 & 5.91 & 1.47 \\
\hline Thailand & 7.98 & 1.35 & 8.58 & 1.33 & 7.28 & 1.20 & 8.06 & 0.95 & 7.97 & 1.21 \\
\hline Ukraine & 6.30 & 2.12 & 4.84 & 1.53 & 7.07 & 2.80 & 4.1 & 1.9 & 6.0 & 1.7 \\
\hline Hungary & 7.46 & 3.39 & 5.72 & 2.24 & 7.49 & 2.30 & 8.6 & 2.3 & 7.1 & 0.4 \\
\hline Czech Republic & 7.25 & 0.42 & 7.92 & 1.33 & 7.90 & 1.10 & 8 & 1 & 6.9 & 1.7 \\
\hline Sweden & 7.35 & 1.80 & 6.16 & 1.94 & 7.90 & 1.10 & 7.2 & 1.3 & 7.0 & 0.4 \\
\hline Switzerland & 6.09 & 1.38 & 4.40 & 2.35 & 8.53 & 1.10 & 4.8 & 2.8 & 5.8 & 1.7 \\
\hline
\end{tabular}
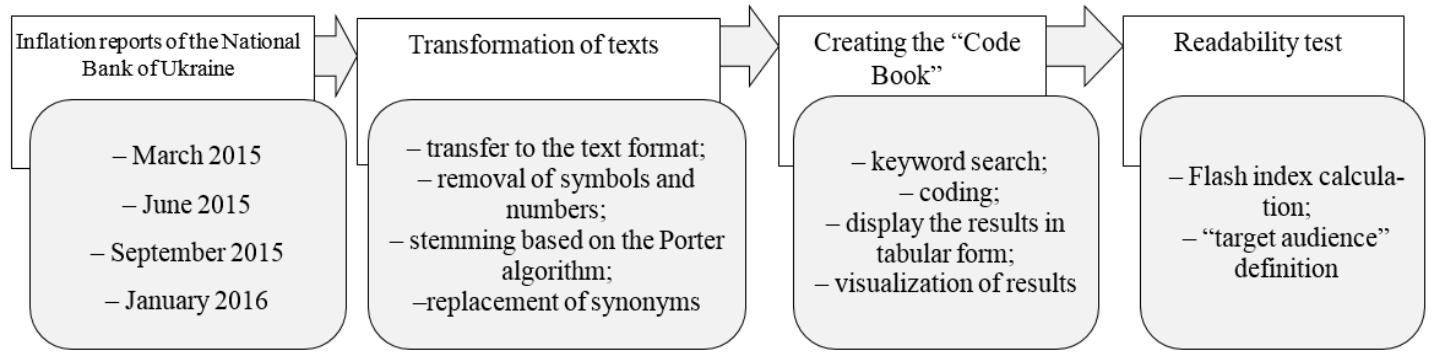

Figure 2. Steps of content analysis of inflation reports of the National Bank of Ukraine 




Figure 3. Results of content analysis of inflation reports of the NBU 